\title{
PERANAN KOPERASI SYARIAH DALAM MENGATASI KEMISKINAN DI KOTA SURABAYA
}

\author{
Nur Aini Yandana Anggi Merisa Putri \\ Lamongan
}

aini.yanda@yahoo.com

\begin{abstract}
This article discusses sharia cooperatives and their role in overcoming poverty in the city of Surabaya. The city of Surabaya is the capital of the province of East Java, the largest and most populous city in East Java. Poverty is a problem that the city government of Surabaya always looks for a solution to. Various programs have been made, including through training, improvement of cooperatives, including Sharia cooperatives. This article is the result of a literature review and is qualitative in nature. The data collected through the literature were analyzed descriptively. The results of the study concluded that the Surabaya government made programs to alleviate poverty, including developing sharia cooperatives. With the existence of Islamic cooperatives, people can manage their funds and develop their businesses through Islamic cooperatives. Even though poverty cannot be eradicated, this effort is one way that can help prosper the community and help overcome existing poverty.
\end{abstract}

Keywords: Sharia cooperatives, BMT, poverty, UKM, Surabaya.

\begin{abstract}
Abstrak: Artikel ini membahas tentang koperasi syariah dan peranannya dalam mengatasi kemiskinan di kota Surabaya. Kota Surabaya merupakan ibu kota provinsi Jawa Timur, kota yang terbesar dan terpadat di Jawa Timur. Kemiskinan menjadi permasalahan yang selalu dicari solusinya oleh pemerintah kota Surabaya. Berbagai program dibuat diantaranya melalui pelatihan-pelatihan, peningkatan koperasi termasuk koperasi Syariah. Artikel ini merupakan hasil kajian pustaka dan bersifat kualitatif. Data yang terkumpul melalui kepustakaan dianalisis secara deskriptif. Hasil penelitian menyimpulkan bahwa pemerintah Surabaya membuat programprogram untuk mengatasi kemiskinan, di antaranya adalah mengembangkan koperasi syariah. Dengan adanya koperasi syariah, masyarakat bisa mengelola dananya dan mengembangkan usahanya melalui koperasi syariah. Meskipun kemiskinan tidak bisa dihapus, namun usaha tersebut merupakan salah satu cara yang dapat membantu mensejahterahkan masyarakat dan membantu mengatasi kemiskinan yang ada.
\end{abstract}

Kata Kunci: Koperasi syariah, BMT, kemiskinan, UKM, Surabaya.

\section{Pendahuluan}

Koperasi adalah badan usaha yang beranggotakan orangorang atau badan usaha hukum koperasi dengan melandaskan

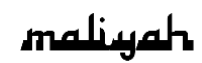

Jurnal Hukum Bisnis Islam

Volume 08, Nomor 01, Juni 2018

p-ISSN: 2088-4869/ e-ISSN: 2597-4351 
kegiatannya berdasarkan prinsip koperasi sekaligus sebagai gerakan ekonomi rakyat yang berdasarkan pada asas kekeluargaan. ${ }^{1}$ Tujuan koperasi adalah untuk mensejahterakan anggotanya. Diharapkan dengan didirikannya lembaga koperasi ini dapat memperbaiki dan memperkokoh perekonomian rakyat Surabaya. Adapun perkembangan koperasi di Surabaya dari setiap tahunnya mengalami peningkatan yang baik, hal ini dibuktikan dengan berdirinya lembaga koperasi syariah. Koperasi syariah adalah badan usaha koperasi yang menjalankan usahanya dengan prinsipprinsip syariah. Adapun tujuan dari koperasi syariah adalah untuk meningkatkan kesejahteraan anggotanya dan kesejahteraan masyarakat dan ikut serta dalam membangun perekonomian Surabaya berdasarkan pada prinsip-prinsip islam. Koperasi syariah mempunyai peranan penting dalam pembangunan ekonomi nasional.

Salah satu cara untuk mengatasi kemiskinan di kota Surabaya adalah dengan mendirikan lembaga koperasi dan UKM. Kota Surabaya adalah Ibu kota di Propinsi Jawa Timur, kota Surabaya merupakan kota terbesar dan kota yang memiliki jumlah populasi penduduk terbesar kedua setelah kota Jakarta. Tidak heran jika kota Surabaya termasuk kota yang menjadi sasaran dari program pemerintah dalam penanggulangan dan pengentasan kemiskinan. Kemiskinan yang terjadi di kota Surabaya menimbulkan dampak negatif terhadap kesejahteraan kehidupan bagi para masyarakat kota Surabaya, baik itu berdampak terhadap ekonomi, pendidikan, politik, kesehatan dan di bidang lainnya. Hal ini diperlukan solusi untuk mengatasi dan meminimalkan jumlah kemiskinan serta dibutuhkan peran dan kebijakan pemerintah untuk dapat menstabilkan keadaan kemiskinan di kota Surabaya, sehingga kota Surabaya menjadi kota yang makmur dan sejahtera yang terhindar dari ancaman kemiskinan.

\footnotetext{
1 Arifin Sitio and Halomoan Tamba, Koperasi: Teori Dan Praktik (Jakarta: Erlangga, 2001), 18.
}

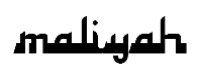

Jurnal Hukum Bisnis Islam 
Banyak penyebab terjadinya kemiskinan yang terjadi di kota Surabaya. Penyebab yang paling dasar adalah karena jumlah pertumbuhan penduduk kota Surabaya yang dari tahun ke tahun mengalami pertumbuhan yang pesat dan kurangnya ketersediaan lapangan pekerjaan di kota Surabaya. Dari keadaan tersebut dapat menimbulkan adanya pengangguran dan kemiskinan.

Ada berbagai macam cara untuk mengatasi tentang permasalahan kemiskinan yang terjadi di kota Surabaya, salah satunya adalah dengan mendirikan lembaga koperasi dan UKM di kota Surabaya. Karena koperasi mempunyai banyak peran penting dalam memperbaiki perekonomian di kota Surabaya. Tujuan koperasi yaitu untuk mensejahterahkan para anggotanya pada khususnya serta kepada para masyarakat pada umumnya. Dengan didirikannya lembaga koperasi diharapkan agar dapat membantu para masyarakat dalam menciptakan perekonomian yang lebih baik dari keadaan perekonomian yang sebelumnya.

\section{Keadaan Perekonomian di kota Surabaya}

Kota surabaya adalah kota terbesar kedua setelah kota Jakarta. Kota Surabaya memiliki banyak potensi di bidang perekonomian. Mayoritas kegiatan perekonomian masyarakat kota Surabaya adalah di bidang perdagangan, jasa, industri, dan juga di bidang pertanian. Kota Surabaya dikenal sebagai salah satu kota perdagangan dan perekonomian yang paling utama di Jawa Timur.

Bukti bahwa kota Surabaya merupakan pusat perekonomian di provinsi Jawa Timur adalah karena di pusat kota Surabaya terdapat banyak perusahaan-perusahaan besar diantaranya, PT Sampoerna Tbk, Maspion, Unilever dan perusahaan besar lainnya. Selain itu di kota Surabaya juga terdapat kawasan industri seperti, Surabaya Industrial Estate Rungkut (SIER) , industri di Margomulyo dan industri-industri yang lainnya.

Sedangkan di bidang perdagangan, kota Surabaya telah bekerja sama dengan sektor swasta untuk menjadikan kota

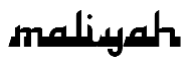


Surabaya sebagai kota perdagangan internasional. Dari kerjasama tersebut banyak pembangunan gedung pusat pembelanjaan modern yang berada di pusat kota Surabaya dengan disertai berbagai fasilitas-fasilitas yang lengkap, diantaranya adalah Tunjungan Plaza, Pakuwon Trade Center, Bubutan Juction, Royal Plaza, City Of Tomorrow (CiTo), Plaza Marina dan pusat pembelanjaan modern lainnya. Selain itu juga terdapat pusat pembelanjaan pasar tradisional di kota Surabaya seperti Pasar Turi, Pasar Atom, Darmo Trade Center (DTC) dan pasar tradisional lainnya.

Akan tetapi jika dilihat dari kehidupan masyarakat kota Surabaya sendiri masih belum menunjukkan kepada kesejahteraan, karena masih banyak masyarakat kota Surabaya yang hidup dalam keadaan miskin. Hal ini perlu adanya solusi untuk mengatasi kemiskinan tersebut dan dibutuhkan peranan pemerintah baik itu dari kebijakan-kebijakannya untuk dapat meminimalkan jumlah kemiskinan di kota Surabaya. Banyak faktor-faktor yang dapat menyebabkan adanya kemiskinan di kota Surabaya. Di antara penyebab yang paling utama adalah karena pertumbuhan jumlah penduduk kota Surabaya yang dari tahun ke tahun semakin meningkat tinggi sedangkan kesediaan lapangan pekerjaan di kota Surabaya masih belum bisa seimbang dibandingkan dengan jumlah penduduk di kota Surabaya.

Sebagai Ibu kota Provinsi Jawa Timur, tidak mengherankan jika Kota Surabaya merupakan kota terpadat penduduknya di Provinsi Jawa Timur. Kepadatan penduduk Kota Surabaya dalam kurun waktu lima tahun (2005 - 2010) terus mengalami peningkatan jumlah penduduk. Pada tahun 2005 jumlah penduduk Kota Surabaya dari hasil registrasi penduduk yang dilakukan oleh Dinas Pendaftaran Penduduk dan Pencatatan Sipil Kota Surabaya sebesar 2.740 .490 jiwa. Kemudian pada tahun 2006, 2007, 2008 dan 2009 terjadi peningkatan jumlah penduduk Kota Surabaya. Jumlah penduduk Kota Surabaya tertinggi pada tahun 2009 sebesar 2.938.225 jiwa, tetapi pada tahun 2010 mengalami penurunan sekitar 8.697 jiwa dari 2.938.225 jiwa menjadi 2.929 .528 jiwa. 
Total Jumlah Penduduk Surabaya Tahun 2011 adalah 3.024.321 jiwa sedangkan jumlah penduduk pada tahun 2012 adalah 3.063.320 jiwa. ${ }^{2}$

Dari data jumlah kependudukan kota Surabaya tersebut, maka dapat disimpulkan bahwa dari setiap tahunnya jumlah penduduk kota Surabaya mengalami peningkatan yang tinggi. Hal ini dapat menyebabkan terjadinya kemiskinan jika dari pertumbuhan jumlah penduduk tersebut tidak di imbangi dengan jumlah kesediaan lapangan pekerjaan. Dengan kondisi tersebut akan berdampak kepada kesejahteraan kehidupan masyarakat kota Surabaya dan juga dapat menimbulkan permasalahan-permasalahan perekonomian seperti pendapatan masyarakat tidak merata, meningkatnya jumlah pengangguran-pengangguran, meningkatnya jumlah kriminalitas di tengah-tengah masyarakat, banyak adanya pemukiman kumuh akibat dari rendahnya tingkat kesehatan dan berbagai permasalahan ekonomi yang lainnya.

\section{Pengertian Koperasi Syariah dan Baitul Maal Wat Tamwil (BMT)}

Koperasi Syariah merupakan sebuah konversi dari koperasi konvensional melalui pendekatan yang sesuai dengan syariat Islam dan meneladani ekonomi yang dilakukan rasulullah dan para sahabatnya. Konsep pendirian koperasi syariah menggunakan konsep Syirkah Mufawadhah yaitu sebuah usaha yang didirikan secara bersama-sama antara dua orang atau lebih. Dari masing-masing pendiri koperasi tersebut memberikan kontribusi dana yang sama besar dan berpartisipasi dalam kerjasama. Dan dari masing-masing pihak saling menanggung satu sama lain dalam hak dan kewajibannya. ${ }^{3}$

2 “No Title," n.d., http://surabayakota.bps.go.id/index.php/pelayananstatistik/statistik-daerah/statistik-paniai-penduduk, 2 April 2012.

3 "Gambaran Tentang Koperasi Syariah," 2009, ttp://bmtsyariah.blogspot.com/2009/11/gambaran-tentang-koperasi-syariah.html. diakses 11 Mei 2012.

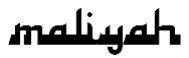


Dewasa ini koperasi syariah menjadi trend di masyaraka sebagai salah satu alternatif pembiayaan usaha rakyat. Dalam aplikasinya koperasi syariah mempunyai kesamaan dengan Baitul Maal Wa Tamwil (BMT).

BMT dalam aplikasinya menerapkan fungsi simpan pinjam layaknya pada koperasi dengan menggunakan instrumen produk yang sedikit banyaknya mengacu pada modernisasi produk perbankan, khususnya perbankan syariah. BMT dalam perkembangannya telah terbukti banyak memberikan kontribusi yang cukup besar pada perkembangan dan penguatan ekonomi pada usaha mikro kecil dan menengah.

BMT (baitul maal wat tamwil) atau padanan kata balai usaha mandiri terpadu adalah lembaga keuangan mikro yang dioperasikan dengan prinsip bagi hasil, menumbuhkembangkan bisnis usaha mikro dan kecil, dalam rangka mengangat derajat dan martabat serta membela kepentingan kaum fakir miskin. ${ }^{4}$

Visi didirikannya lembaga BMT (baitul maal wat tamwil) adalah untuk mewujudkan BMT menjadi lembaga yang mampu meningkatkan kualitas ibadah anggota, sehingga mampu berperan sebagai wakil-pengabdi Allah SWT, memakmurkan kehidupan anggota pada khususnya dan masyarakat pada umumnya. Sedangkan misi didirikannya lembaga BMT adalah untuk membangun dan mengembangkan tatanan perekonomian dan struktur masyarakat madani yang adil berkemakmuran-berkemajuan, serta makmur-maju berkeadilan berlandaskan Syariah dan ridho Allah SWT. ${ }^{5}$

Tujuan didirikannya lembaga BMT adalah untuk meningkatkan kualitas usaha ekonomi untuk kesejahteraan anggota pada khususnya dan masyarakat pada umumnya. Dengan menjadi anggota BMT, masyarakat dapat meningkatkan taraf hidup melalui peningkatan usahanya. ${ }^{6}$

\footnotetext{
${ }^{4}$ Fitri Nurhartati, Koperasi Syariah (Surakarta: PT Era Intermedia, 2008), 49.

${ }^{5}$ Muhammad Ridwan, Manajemen BMT(Yogyakarta: UII Press, 2004), 127.

6 Ibid., 128.
} 
Dalam rangka untuk mencapai semua tujuannya, BMT berfungsi untuk: ${ }^{7}$

1. Mengidentifikasi, memobilitasi, mengorganisasi, mendorong dan mengembangkan potensi serta kemampuan potensi ekonomi anggota, kelompok anggota muamalat (pokusma) dan daerah kerjanya.

2. Meningkatkan kualitas SDM enggota dan pokusma menjadi lebih profesional dan Islami sehingga semakin utuh dan tangguh dalam menghadapi persaingan global.

3. Menggalang dan memobilisasi potensi masyarakat dalam rangka meningkatkan kesejateraan anggota.

4. Menjadi perantara keuangan (financial intermediary) antara agniya sebagai shohibul mall dengan du'afa sebagai mudhorib, terutama untuk dana-dana sosial seperti zakat, infaq, sedekah, wakat, hibah dan lain-lain.

5. Menjadi perantara keuangan (financial intermediary), antara pemilik dana (shahibul mal), baik sebagai pemodal maupun penyimpan dengan pengguna dana (mudharib) untuk pengembangan usaha produktif.

Adapun azas usaha koperasi syariah berdasarkan konsep gotong royong dan tolong-menolong, yaitu tidak dimonopoli oleh salah seorang pemilik modal saja. Begitupun juga dalam hal keuntungan dan kerugian yang diperoleh dibagi secara sama dan proporsional.

Koperasi syariah juga berlandasan pada syariat Islam yaitu al-Qur'an dan As-Sunnah, dan berlandaskan pada Pancasila dan Undang-Undang Dasar 1945 dengan berazaskan kekeluargaan saling tolong menolong (ta'awun) dan saling menguatkan (takaful). Sebagaimana dijelaskan dalam al-Qur'an surat Al-Maidah ayat 2, yang artinya "Dan tolong menolonglah kamu dalam (mengerjakan) kebajikan dan taqwa, dan jangan tolong menolong dalam berbuat dosa dan pelanggaran. Dan bertaqwalah kamu kepada Allah, Allah amat berat siksaannya".

7 Ibid., 131. 
Ekonomi syariah berbasis pada sistem bagi hasil. Akadakad dalam praktek keuangan syariah pada hakekatnya merupakan akad-akad di sektor rill. Mudharabah dan musyarakah akan eksis kalau ada jenis usaha rill yang dilakukan. Akad mudharabah akan terlaksana kalau ada barang rill yang di perjual belikan. Begitu pula dengan akad-akad lainnya. Sektor keuangan akan selalu bersesuaian dengan sektor rill. Maju mundurnya sektor keuangan sangat ditentukan oleh maju tidaknya sektor rill. Filosofi yang sama tidak akan pernah kita temukan pada konsep ekonomi konvensional. ${ }^{8}$

Hafiduddin mengajak seluruh elemen bangsa untuk bersama-sama mengembangkan sistem ekonomi syariah. Dalam konteks ini, ada beberapa sektor ekonomi syariah yang perlu untuk di-manage secara lebih serius kedepan. Sektorsektor yang telah diidentifikasi tersebut juga merupakan peluang menarik bagi koperasi syariah yaitu:

1. Zakat, Infak dan Sedekah (ZIS). Karena tanpa disadari ZIS adalah salah satu potensi besar dalam mengatasi problematika kemiskinan. Rasulullah saw bersabda "sesungguhnya Allah swt telah meewajibkan atas hartawan Muslim suatu kewajiban zakat yang dapat menanggulangi kemiskinan. Tidaklah mungkin terjadi seorang fakir menderita kelaparan atau kekurangan pakaian, kecuali oleh sebab kebakhilan yang ada pada hartawan muslim" (HR Imam Al-Asbahani).

Paradigma kita tentang ZIS harus diubah, ia bukanlah penyebab berkurangnya harta tetapi ia adalah sumber investasi yang dapat menggerakan perekonomian kelompok masyarakat lemah pada umumnya bersatu dalam wadah koperasi. Karena jika kaum dhuafa ini terberdayakan maka dengan tersendirinya perekonomian negara secara keseluruhan pun akan bergerak dan berkembang.

8 Abdul Basith, Islam Dan Manajemen Koperasi (Malang: UIN Maliki Press, 2008), 29-31. 
2. Wakaf, termasuk wakaf uang ( sering disebut wakaf tunai ). Salah satu sumber utama penyebab kuatnya perekonomian mereka adalah karena wakaf tunai. wakaf tunai telah menjadi inspirasi kejayaan peradapan Turki. Ia adalah potensi sumber pendanaan yang sangat luar biasa jika mampu dikelola dengan baik. Indonesia tidak perlu berhutang kepada negara-negara kaya jika ia mampu menggali potensi wakaf tunai. Untuk itu, pemerintah harus secara serius memikirkan penggalian poetensi wakaf ini. Lahir dan tumbuhnya Badan Wakaf Indonesia (BWI) merupakan suatu keniscayaan sekaligus sebagai sumber kebutuhan.

3. Perbankan syariah, sektor ini harus didukung agar terus berkembang. Pemerintah harus menunjukkan komitmen yang kuat untuk membantu berkembangnya industri perbankan syariah.

4. Sukuk atau obligasi syariah, sukuk adalah instrumen yang mampu mendorong pada peningkatkan arus investasi ke tanah air.

5. Tumbuhnya Lembaga Keuangan Mikro (LKM) syariah, seperti BMT (Baitul Maal wat Tamwil). Mengembangkan sektor usaha kecil dan menengah (UKM) merupakan sesuatu yang tidak bisa di tawar-tawar lagi. Salah satu negara yang maju karena dikuatkan UKM adalah Jepang. BMT pada dasarnya merupakan ujung tombak pemberdayaan kelompok dhuafa.

6. Sektor keuangan lainnya, seperti pasar modal syariah, asuransi syariah, pengadaian syariah, lembaga keuangan koperasi dan lain-lain. Mengembangkan ekonomi syariah merupakan salah satu jawaban untuk mengeluarkan bangsa ini dari keterpurukan ekonomi. ${ }^{9}$

\section{Penyebab Kemiskinan di Kota Surabaya}

Ada beberapa penyebab yang mengakibatkan adanya kemiskinan yang terjadi di kota Surabaya. Dari berbagai

${ }^{9}$ Ibid., 32-37. 
penyebab atau faktor-faktor terjadinya kemiskinan tersebut banyak membawa pengaruh bagi perkembangan dan pertumbuhan perekonomian di kota Surabaya serta membawa dampak bagi kehidupan para masyarakat penduduk di kota Surabaya.

Adapun faktor-faktor penyebab terjadinya kemiskinan di kota Surabaya diantaranya adalah sebagai berikut:

1. Jumlah pertumbuhan penduduk di kota Surabaya yang tinggi

Pertumbuhan penduduk yang sedemikian cepat dapat menimbulkan masalah yang serius bagi kesejahteraan umat manusia diseluruh dunia. ${ }^{10}$ Begitu juga pertumbuhan penduduk yang terjadi di kota Surabaya akan dapat menimbulkan berbagai permasalahan ekonomi seperti tidak meratanya pendapatan masyarakat kota Surabaya dan menurunnya kualitas hidup perkapita bagi para penduduk di kota Surabaya.

2. Kesediaan lapangan pekerjaan yang Terbatas

Dengan bertambahnya jumlah penduduk di kota Surabaya dan tidak di imbangi dengan jumlah kesediaan lapangan pekerjaan maka akan dapat mengakibatkan terjadinya kemiskinan di kota Surabaya. Dari keadaan tersebut maka dapat menimbulkan meningkatnya jumlah pengangguran di kota Surabaya.

3. Perbedaan kualitas sumber daya manusia di masyarakat kota Surabaya

Kualitas sumber daya manusia dari setiap masingmasing masyarakat mempunyai perbedaan. Ada seseorang yang kualitas sumber daya manusianya tinggi ada juga yang kualitas sumber daya manusianya rendah. Dan jika dari suatu wilayah tertentu banyak masyarakat yang memiliki kualitas sumber daya manusia yang rendah maka akan sulit bersaing dengan masyarakat lain yang kualitas sumber daya manusianya tinggi. Kualitas sumber daya manusia berasal

${ }^{10}$ Michael P. Todaro, Pembangunan Ekonomi (Jakarta: Bumi Aksara, 2000), 204. 
dari kualitas pendidikannya, keahlian suatu masyarakatnya dan juga keterampilannya.

4. Pendapatan atau penghasilan yang rendah

Seseorang dikatakan miskin jika sumber daya ekonomi yang dimilikinya rendah atau dibawah patokan yang sudah ditentukan. Dengan keadaan ini masyarakat cenderung tidak bisa meningkatkan taraf hidupnya dalam memenuhi semua kebutuhannya di karenakan jumlah pendapatan yang rendah. Hal ini dapat mengakibatkan terjadinya kemiskinan.

5. Kualitas pendidikan yang rendah dan jaminan kehidupan yang rendah

Pendidikan yang rendah dan jaminan kehidupan yang rendah juga dapat menyebabkan terjadinya kemiskinan. Karena dengan pendidikan yang rendah akan sulit untuk bersaing dengan yang lainnya secara baik dan kurangnya pengetahuan yang dimilikinya serta kurangnya keahlian dan keterampilan.

6. Jumlah pengangguran yang tinggi

Jumlah pengangguran di kota Surabaya dari tahun ke tahun sangat meningkat dengan cepat. Kebanyakan masyarakat yang menjadi pengangguran disebabkan karena sumber daya manusia yang dimiliki sangat rendah hal ini dikarenakan faktor kualitas pendidikan yang rendah, tidak memiliki banyak keahlian serta keterampilan dalam bekerja. Di kota Surabaya tercatat jumlah pengangguran di kota Surabaya sebanyak 802.568 warga. Oleh karena itu dibutuhkan peran pemerintah dalam mengatasi permasalahan tentang pengangguran dan juga masalah ekonomi lainnya. Agar kota Surabaya menjadi kota yang makmur dan sejahtera.

7. Adanya bencana alam

Terjadinya bencana alam dapat mengakibatkan terjadinya kemiskinan. Karena dampak dari bencana alam mengakibatkan semua kekayaan yang dimiliki masyarakat menjadi hilang. Seperti kejadian bencana alam di kota Sidoarjo yaitu bencana alam lumpur lapindo. Dari bencana alam tersebut banyak masyarakat yang kehilangan 
kekayaannya seperti rumah, harta benda, pekerjaan bahkan keluarga-keluarganya. Keadaan tersebut menimbulkan banyak orang yang menjadi pengangguran, dari pengangguran tersebut terjadilah kemiskinan yang tidak bisa dihindarkan.

Dari semua penyebab kemiskinan dan masalah yang lainnya perlu cara untuk mengatasi serta memperbaiki keadaan menjadi lebih baik agar terwujudnya kehidupan masyarakat yang makmur dan sejahtera. Oleh karena itu dibutuhkan kerjasama antara pemerintah dengan masyarakat kota Surabaya untuk memperbaiki keadaan menjadi lebih baik lagi.

\section{Koperasi dan Peranannya dalam Mengatasi Kemiskinan}

Pengertian koperasi dapat dilakukan dari pendekatan asal yaitu kata koperasi berasal dari Bahasa Latin coopere atau cooperation dalam Bahasa Inggris. Co berarti bersama dan operation berarti bekerja. Jadi, cooperation berarti bekerjasama. Dalam hal ini, bekerjasama yang dilakukan oleh orang-orang yang mempunyai kepentingan dan tujuan yang sama. Kerjasama dalam bidang ekonomi disebut economic cooperation. ${ }^{11}$

Definisi koperasi menurut Moh. Hatta sebagai pendiri lembaga koperasi adalah usaha bersama untuk memperbaiki nasib penghidupan ekonomi berdasarkan tolong-menolong. ${ }^{12}$ Sedangkan definisi koperasi menurut UU No. 25 Tahun 1992 tentang perkoperasian, koperasi adalah badan usaha yang beranggotakan orang-orang atau badan hokum koperasi, dengan melandaskan kegiatannya berdasarkan prinsip koperasi sekaligus sebagai gerakan ekonomi rakyat, yang berdasar atas azas kekeluargaan. ${ }^{13}$

\footnotetext{
${ }^{11}$ Sitio and Tamba, Koperasi: Teori Dan Praktik, 16.

12 Ibid., 17.

13 “Undang-Undang Nomor 25 Tahun 1992 Tentang Perkoperasian,” 1992.
} 
Adapun pengertian koperasi menurut pendapat Hans $\mathrm{H}$. Muenkner dapat dibedakan sebagai berikut:

1. Dalam arti ekonomi

Koperasi adalah organisasi ekonomi yang anggotanya memiliki sekurang-kurangnya satu kepentingan ekonomi yang sama, bermotivasi swadaya dalam perusahaan yang dibiayai dan diawasi bersama dengan sasaran meningkatkan kemajuan perusahaan rumah tangga anggota (promosi anggota).

2. Dalam arti sosiologi

Organisasi koperasi adalah perkumpulan orang-orang yang bekerjasama selama satu periode tertentu atas dasar persamaan dan dibawah suatu kepemimpinan yang diawasi secara demokratis untuk mengatasi kesulitan-kesulitan bersama. ${ }^{14}$

Jenis-jenis koperasi adalah:

1. Koperasi Konsumsi

Koperasi konsumsi adalah jenis koperasi konsumen. Anggota koperasi konsumsi memperoleh barang dan jasa dengan harga lebih murah, lebih mudah, lebih baik dan dengan pelayanan yang menyenangkan.

2. Koperasi Produksi

Koperasi produksi disebut juga koperasi pemasaran. Koperasi produksi didirikan oleh anggota yang bekerja di sektor usaha produksi seperti petani, pengrajin, peternak, dan sebagainya.

3. Koperasi Jasa

Koperasi jasa didirikan bagi calon anggota yang menjual jasa. Misalnya, usaha distribusi, usaha perhotelan, angkutan, restoran, dan lain-lain.

4. Koperasi Simpan Pinjam

14 Bernhard Limbong, Pengusaha Koperasi: Memperkokoh Fondasi Ekonomi Rakyat (Jakarta: Margaretha Pustaka, 2010), 63. 
Peranan Koperasi Syariah Dalam Mengatasi ...

Koperasi simpan pinjam didirikan untuk mendukung kepentingan anggota yang membutuhkan tambahan modal usaha dan kebutuhan finansial lainnya.

\section{Single Purpose dan multi Purpose}

Koperasi single purpose adalah koperasi yang aktivitasnya terdiri satu macam, sedangkan koperasi multi purpose adalah koperasi yang didirikan oleh para anggotanya untuk dua atau lebih jenis usaha. ${ }^{15}$

Koperasi mempunyai peranan yang penting dalam membangun perkembangan serta pertumbuhan perekonomian di Indonesia, begitupun juga pertumbuhan perekonomian di kota Surabaya. Koperasi berlandaskan pada pancasila dan UUD 1945, sedangkan asasnya adalah asas kekeluargaan. Landasan operasionalnya adalah Undang-Undang RI Nomor 25 tahun 1992 tentang perkoperasian sebagai penganti Undang-Undang RI Nomor 12 tahun 1967.16

Peran koperasi menurut Undang-Undang No. 25 tahun 1992 Pasal 4 adalah ${ }^{17}$ :

1. Membangun dan mengembangkan potensi serta kemampuan ekonomi anggota pada khususnya dan masyarakat pada umumnya untuk meningkatkan kesejahteraan ekonomi dan sosialnya.

2. Berperan serta secara aktif dalam upaya mempertinggi kualitas kehidupan manusia dan masyarakat.

3. Memperkokoh perekonomian rakyat sebagai dasar kekuatan dan ketahanan perekonomian nasional dengan koperasi sebagai soko gurunya.

4. Berusaha untuk mewujudkan dan mengembangkan perekonomian nasional yang merupakan usaha bersama atas asas kekeluargaan dan demokrasi ekonomi.

${ }^{15}$ Limbong, Pengusaha Koperasi: Memperkokoh Fondasi Ekonomi Rakyat, 7576.

${ }^{16}$ Limbong, Pengusaha Koperasi: Memperkokoh Fondasi Ekonomi Rakyat, 65.

17 Undang-Undang Nomor 25 Tahun 1992 pasal 4 Tentang Fungsi dan Peran Koperasi 
Adapun tujuan koperasi menurut prof. Dr. Tiktik S. partomo, tujuan perusahaan koperasi antara lain: ${ }^{18}$

1. Mempertahankan, jika mungkin meningkatkan bagian pasar dari satu (beberapa) barang dan jasa dan menekan serendah-rendahnya biaya produksi yang harus lebih rendah atau sekurang-kurangnya sama dengan biaya produksi para pesaingnya.

2. Melindungi potensi ekonominya, menjaga atau mengamankan likuiditasnya dan menciptakan inovasi.

Berdasarkan watak dan ideologinya, koperasi merupakan media yang sangat strategis bagi pemerintah untuk memerangi kemiskinan di Surabaya. Dengan prinsip asas kekeluargaan, koperasi merupakan media yang menghimpun secara sinergis kekuatan-kekuatan ekonomi rakyat yang lemah dan kecil melalui penguasaan asset produktif secara kolektif, mengingat salah satu faktor penyebab orang menjadi miskin adalah karena tidak memiliki aset produktif yang akan digunakan untuk menciptakan kemandirian ekonomi.

Jadi peran koperasi sebagai soko guru perekonomian nasional tidak hanya sekedar untuk meningkatkan pendapatan para anggotanya tetapi juga harus mampu meningkatkan kepemilikan asset produktif bagi anggotanya. Melalui koperasi yang berbasis komunitas diharapkan akan dapat dibangun kesejahteraan secara bersama (kolektif) dan memunculkan semangat gotong royong sebagai ruh dari ekonomi kerakyatan.

\section{Peranan Koperasi Syariah dalam Mengatasi Kemiskinan di Kot Surabaya}

Dari beberapa penyebab kemiskinan yang terjadi di kota Surabaya tersebut, maka dibutuhkan solusi atau cara untuk mengatasi masalah kemiskinan di Surabaya. Salah satu solusi untuk mengatasi permasalahan tersebut adalah mendirikan lembaga koperasi yaitu dengan meningkatan peran dan pemberdayaan koperasi di kota Surabaya.

${ }^{18}$ Ibid., 67. 
Karena jumlah kemiskinan di kota Surabaya yang dari tahun ke tahun mengalami pertumbuhan maka Pemerintah Kota Surabaya selalu berupaya untuk meminimalkan jumlah kemiskinan dengan cara melakukan pembinaan potensi masyarakat di kota Surabaya, terutama dalam pemberdayaan ekonomi kerakyatan. Pemberdayaan usaha mikro, kecil dan menengah (UMKM) dan Koperasi merupakan langkah yang strategis dalam meningkatkan dan memperkuat dasar kehidupan perekonomian dari sebagian terbesar rakyat Surabaya, khususnya melalui penyediaan lapangan kerja dan mengurangi kesenjangan dan tingkat kemiskinan.

Hal ini dapat dilakukan dengan melalui gerakan koperasi di Kota Surabaya. Dari kebijakan yang dilakukan pemerintah kota Surabaya tersebut telah membuahkan hasil, hal ini dibuktikan sudah banyak lembaga koperasi yang berdiri di kota Surabaya.

Berdasarkan data Dinas Koperasi dan UKM Kota Surabaya tahun 2010, jumlah koperasi di Surabaya sebanyak 1.428 koperasi sedangkan koperasi yang aktif sebanyak 1.183 koperasi dengan SHU sebesar Rp 160. 731.885.000. Dengan jumlah tersebut, secara langsung maupun tidak langsung sangat menunjang kesuksesan pembangunan Kota Surabaya, mengingat jumlah tenaga kerja yang terserap didalamnya mencapai 3.710 orang. Jumlah pembinaan potensi masyarakat melalui gerakan koperasi yang dilakukan pemerintah kota Surabaya adalah sebesar 1.100 koperasi. Jadi tingkat pertumbuhan koperasi di Surabaya ini mencapai 6 persen dalam setahun. Jumlah koperasi di Surabaya saat ini adalah sekitar 1.500 unit koperasi. Dari hasil perkembangan koperasi di kota Surabaya tersebut maka kota Surabaya berhasil dalam meraih dan menerima penghargaan sebagai salah satu kota penggerak koperasi di Jawa Timur. Penghargaan tersebut merupakan awal akselerasi pembangunan perkoperasian di Kota Surabaya. ${ }^{19}$

19 “No Title," 2011, http://antarajatim.com/lihat/berita/66738/surabaya-raihpenghargaan-kota-penggerak-koperasi-2011, diakses 2 April 2012. 
Perkembangan lembaga koperasi di Surabaya dari tahun ke tahun mengalami peningkatan yang pesat dan memberikan konstribusi bagi kehidupan masyarakat kota Surabaya. Bahkan tingkat pertumbuhan koperasi di Surabaya ini paling tinggi di Surabaya karena dalam periode setahun terbentuk lembaga koperasi baru sebanyak 50 hingga 60 koperasi per tahunnya di beberapa daerah kota Surabaya.

Untuk mengembangkan lembaga koperasi di Surabaya, pemerintah kota Surabaya membentuk suatu instansi yaitu mendirikan Dinas Koperasi dan UKM di kota Surabaya yaitu yang berada di Jl. Raya Juanda, Surabaya Jawa Timur, yang diketuai oleh Hadi Mulyono. Misi didirikannya lembaga Dinas Koperasi dan UKM di kota Surabaya adalah menciptakan para wirausaha dan pengusaha-pengusaha baru. Dinas koperasi dan UKM Surabaya mempunyai agenda dan tugas besar yang harus dilakukan yaitu mengurangi masalah kemiskinan dan pengangguran di kota Surabaya.

Adapun tujuan pemerintah dalam mendirikan Dinas Koperasi dan UKM di kota Surabaya ini adalah untuk mensejahterakan kehidupan masyarakat di kota Surabaya dan juga untuk mengurangi jumlah kemiskinan, dengan cara:

1. Menciptakan iklim usaha yang kondusif.

2. Mengembangkan kewirausahaan yang unggul dan kompetisi.

3. Meningkatkan partisipasi masyarakat dan dunia usaha untukpemberdayaan koperasi dan UKM yang terpadu.

4. Meningkatkan peran terhadap usaha kecil.

5. Meningkatkan kontribusi dalam pertumbuhan produktivitas daerah

6. Serta untuk meningkatkan pertumbuhan ekonomi dan menciptakan lapangan pekerjaan.

Lembaga koperasi di kota Surabaya telah berhasil menjalankan agenda besarnya dalam mengatasi masalah kemiskinan dan pengangguran di kota Surabaya. Sebagaimana data dari dinas koperasi jumlah kemiskinan di kota Surabaya pada tahun 2010 mencapai 5.529 .300 sedangkan jumlah kemiskinan pada tahun 2012 turun menjadi 5.356.210.

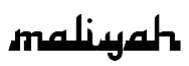


Begitu juga dengan masalah pengangguran di kota Surabaya, berdasarkan hasil survai BPS mengenai masalah pengangguran di Surabaya sedikit demi sedikit mulai teratasi. Data tersebut menyebutkan, angka pengangguran selama tiga tahun belakangan di Surabaya mengalami penurunan. Kepala BPS Patris Sayogya mengatakan, angka pengangguran pada 2007 mencapai 87.939 orang atau 7,04 persen. Namun, menurut pendataan terakhir BPS, angka pengangguran pada 2009 turun hingga 85.000 orang. Jika dipersentasekan, angkanya hanya 6,82 persen. ${ }^{20}$

Data Surabaya yang dikutip dari BPS Surabaya mencatat persentase penduduk miskin di Surabaya kian menurun. Angka penduduk miskin ini terus menurun sejak 2015. Menurut data BPS Surabaya persentase penduduk miskin Kota Surabaya tahun 2018 menurun. Penurunan terus terjadi dari 2016 yakni 5,63 persen, diikuti 2017 sebesar 5,39 persen. Pada 2018, persentase penduduk miskin Surabaya mencapai 4,88 persen. ${ }^{21}$

Pada tahun 2018, Garis Kemiskinan Kota Surabaya berada pada level Rp 530.178,- per Kapita per Bulan atau meningkat hampir 56 ribu rupiah dibanding Garis Kemiskinan pada tahun 2017. Walaupun terjadi kenaikan Garis Kemiskinan, jumlah penduduk miskin pada tahun 2018 di Kota Surabaya justru berkurang hampir 14 ribu orang lebih menjadi hampir mencapai 141 ribu orang $(4,88$ persen) dibanding kondisi tahun 2017 yang hampir mencapai 155 ribu orang (5,39 persen). Seiring penurunan persentase penduduk miskin, rata-rata kesenjangan pengeluaran penduduk miskin terhadap Garis Kemiskinan tercatat sedikit bertambah dangkal yang diindikasikan oleh Indeks Kedalaman Kemiskinan (P1) Kota Surabaya pada tahun 2018 yang semakin dangkal 0,29 poin dibanding tahun sebelumnya menjadi 0,81 poin. Begitu pula ketimpangan pengeluaran di antara penduduk miskin di Kota

20 (http://www.infokerja-jatim.com/?m=detail berita\&id=168, di akses 17 Mei 2012)

21 Https:/surabaya.liputan6.com/, "Data Surabaya: Jumlah Penduduk Miskin Turun Sejak 2015," n.d., https://surabaya.liputan6.com/read/4059324/datasurabaya-jumlah-penduduk-miskin-turun-sejak-2015. 
Surabaya juga tercatat sedikit merapat yang diindikasikan oleh adanya sedikit penurunan pada Indeks Keparahan Kemiskinan (P2) sekitar 0,13 poin menjadi 0,20 poin dibanding keadaan tahun 2017.22

Penerapan sistem ekonomi syariah dapat menjadi salah satu upaya untuk meningkatkan kesejahteraan masyarakat. Dinas Koperasi dan Usaha Mikro Kecil dan Menengah (Dinkop \& UMKM) di Jawa Timur selain mendirikan lembaga koperasi konvensional juga mengembangkan pelaksanaan kegiatan usaha koperasi dengan berbasis Islam yaitu koperasi syariah. Pola pengembangannya beragam, yaitu dengan cara mengadakan pembinaan terhadap anggota koperasi maupun seminar.

Hal tersebut diungkapkan Humas Pejabat Pengelola Informasi dan Dokumentasi (PPID) Dinkop \& UMKM Jatim, Setyo Budi Wahono, dia mengatakan koperasi syariah akan dikembangkan untuk memberikan layanan terbaik terhadap anggota koperasi. ${ }^{23}$

Produk pembiayaan koperasi syariah di Jawa Timur terdiri dari 3 kategori, yaitu jual-beli, bagi hasil, dan sewa. Sedangkan transaksi penyaluran dana berdasarkan akad bagi hasil dapat dilakukan dalam 2 jenis, yakni mudharabah dan musyarakah:

1. Mudharabah adalah akad kerja sama usaha atau perniagaan antara pihak pemilik dana (sahibul maal)sebagai pihak yang menyediakan modal sebesar $100 \%$ dengan pihak pengelola modal (mudharib), untuk diusahakan dengan porsi keuntungan akan di bagi bersama (nisbah) sesuai dengan kesepakatan dimuka dari kedua belah pihak, sedangkan jika ada kerugian akan ditanggung pemilik modal, kecuali jika

\footnotetext{
${ }^{22}$ Badan Pusat Statistik Kota Surabaya, "Profil Kemiskinan Di Kota Surabaya Tahun 2018," Http://Dpm-Ptsp.Surabaya.Go.Id/, 2018, http://dpmptsp.surabaya.go.id/v3/po-content/po-upload/pdrb-2010-2016/ProfilKemiskinan-Kota-Surabaya-2018.pdf. 23 "No Title,", n.d., http://www.surabayapost.co.id/?mnu=berita\&act=view\&id=0ec360c243d4a232 44accb3d04851604\&jenis=e4da3b7fbbce2345d7772b0674a318d5.
} 
ditemukan adanya kelalaian atau kesalahan oleh pihak pengelola dana (mudharib).

2. Musyarakah (syirkah) adalah suatu bentuk akad kerjasama perniagaan antara beberapa pemilik modal untuk menyertakan modalnya dalam suatu usaha, dimana masingmasing pihak mempunyai hak untuk ikut serta dalam pelaksanaan manajemen usaha tersebut. Keuntungan dibagi menurut proporsi pernyataan modal atau berdasarkan kesepakatan bersama. Musyarakah dapat di artikan pula sebagai pencampuran dana untuk tujuan pembagian keuangan. ${ }^{24}$

Adapun peran koperasi syariah dalam memperbaiki perekonomian di kota Surabaya adalah sebagai berikut:

1. Membangun dan mengembangkan potensi dan kemampuan anggota pada khususnya, dan masyarakat pada umumnya, guna meningkatkan kesejahteraan sosial ekonominya;

2. Memperkuat kualitas sumber daya insani anggota, agar menjadi lebih amanah, professional (fathonah), konsisten, dan konsekuen (istiqomah) di dalam menerapkan prinsipprinsip ekonomi Islam dan prinsip-prinsip syariah Islam;

3. Berusaha untuk mewujudkan dan mengembangkan perekonomian nasional yang merupakan usaha bersama berdasarkan azas kekeluargaan dan demokrasi ekonomi;

4. Sebagai mediator antara menyandang dana dengan penggunan dana, sehingga tercapai optimalisasi pemanfaatan harta;

5. Menguatkan kelompok-kelompok anggota, sehingga mampu bekerjasama melakukan kontrol terhadap koperasi secara efektif;

6. Mengembangkan dan memperluas kesempatan kerja;

7. Menumbuhkan-kembangkan usaha-usaha produktif anggota.

Saat ini di Surabaya terdapat sekitar 1700 koperasi dan 54 diantaranya merupakan koperasi syariah. ${ }^{25}$ Kota Surabaya

${ }_{25}^{24}$ Nurhartati, Koperasi Syariah, 40.

25 “Http://Nik.Depkop.Go.Id/," n.d. 
adalah kota terbesar dan kota yang memiliki jumlah populasi penduduk terbesar kedua setelah kota Jakarta. Tidak heran jika kota Surabaya termasuk kota yang menjadi sasaran dari program pemerintah dalam penanggulangan dan pengentasan kemiskinan.

Hal ini perlu adanya solusi untuk mengatasi kemiskinan tersebut dan dibutuhkan peranan pemerintah baik itu dari kebijakan-kebijakannya untuk dapat meminimalkan jumlah kemiskinan di kota Surabaya. Dan salah satu caranya adalah menerapkan sistem ekonomi syariah ke dalam koperasi yang dapat menjadi salah satu upaya untuk meningkatkan kesejahteraan masyarakat. Penerapan sistem ekonomi syariah tidak dimaksudkan untuk menjadikan sistem ekonomi yang radikal. Akan tetapi untuk menata perekonomian yang lebih beradab, bermoral dan berkeadilan.

Koperasi syariah mempunyai peranan penting dalam pembangunan ekonomi nasional, yaitu membangun dan mengembangkan potensi dan kemampuan anggota pada khususnya, serta masyarakat pada umumnya. Peranan koperasi syariah diantaranya adalah: meningkatkan kesejahteraan sosial ekonominya, memperkuat kualitas sumber daya insani anggota agar menjadi lebih amanah, profesional (fathonah), konsisten, dan konsekuen (istiqomah) di dalam menerapkan prinsipprinsip ekonomi Islam dan prinsip-prinsip syariah Islam, serta berusaha untuk mewujudkan dan mengembangkan perekonomian nasional yang merupakan usaha bersama berdasarkan pada azas kekeluargaan dan demokrasi ekonomi, sebagai mediator antara menyandang dana dan lainnya, menguatkan kelompok-kelompok anggota, sehingga mampu bekerjasama melakukan kontrol terhadap koperasi secara efektif, mengembangkan dan memperluas kesempatan kerja, dan menumbuhkan-kembangkan usaha-usaha produktif anggota.

\section{Penutup}

Berdasarkan pembahasan di atas dapat diketahui bahwa Surabaya merupakan kota terbesar kedua di Indonesia setelah 
Jakarta. Sebagaimana permasalahan kota besar lainnya, kemiskinan merupakan salah satu masalah yang dihadapi kota Surabaya. Dengan berbagai programnya, pemerintah Surabaya berusaha mengurangi kemiskinan, di antara melalui pembinaan dan pelatihan UMKM dan mengembangkan koperasi. Di antara koperasi yang berkembang di Surabaya adalah koperasi syariah dengan berbagai produknya. Keberadaan koperasi tersebut merupakan salah satu cara yang diupayakan dapat mengurangi kemiskinan di Surabaya.

Berdasarkan data Badan Pusat Statistik Kota Surabaya, semenjak 2015, diketahui bahwa kemiskinan di kota Surabaya mengalami penurunan. Hal tersebut tidak terlepas dari berbagai program yang dicanangkan pemerintah kota Surabaya, diantaranya melalui koperasi syariah.

\section{Daftar Pustaka}

Abdul, Basith. Islam Dan Manajemen Koperasi. Malang: UIN Maliki Press, 2008.

Badan Pusat Statistik Kota Surabaya. "Profil Kemiskinan Di Kota Surabaya Tahun 2018." Http://DpmPtsp.Surabaya.Go.Id/. 2018. http://dpmptsp.surabaya.go.id/v3/po-content/po-upload/pdrb2010-2016/Profil-Kemiskinan-Kota-Surabaya-2018.pdf.

“Gambaran Tentang Koperasi Syariah,” 2009. ttp://bmtsyariah.blogspot.com/2009/11/gambaran-tentangkoperasi-syariah.html.

"Http://Nik.Depkop.Go.Id/," n.d. Https:/surabaya.liputan6.com/. "Data Surabaya: Jumlah

Penduduk Miskin Turun Sejak 2015," n.d. https://surabaya.liputan6.com/read/4059324/datasurabaya-jumlah-penduduk-miskin-turun-sejak-2015.

Limbong, Bernhard. Pengusaha Koperasi: Memperkokoh Fondasi Ekonomi Rakyat. Jakarta: Margaretha Pustaka, 2010.

"No Title," n.d.

http://www.surabayapost.co.id/?mnu=berita\&act=view\&i $\mathrm{d}=0 \mathrm{ec} 360 \mathrm{c} 243 \mathrm{~d} 4 \mathrm{a} 23244 \mathrm{accb} 3 \mathrm{~d} 04851604$ \&jenis $=\mathrm{e} 4 \mathrm{da} 3 \mathrm{~b}$ 7fbbce2345d7772b0674a318d5. 
Nurhartati, Fitri. Koperasi Syariah. Surakarta: PT Era Intermedia, 2008.

"Pelayanan Statistik," n.d.

http://surabayakota.bps.go.id/index.php/pelayananstatistik/statistik-daerah/statistik-paniai-penduduk.

Ridwan, Muhammad. Manajemen BMT. Yogyakarta: UII Press, 2004.

Sitio, Arifin, and Halomoan Tamba. Koperasi: Teori Dan Praktik. Jakarta: Erlangga, 2001.

"Surabaya Raih Pernghargaan Kota Penggerak Koperasi," 2011. http://antarajatim.com/lihat/berita/66738/surabayaraih-penghargaan-kota-penggerak-koperasi-2011.

Todaro, Michael P. Pembangunan Ekonomi. Jakarta: Bumi Aksara, 2000.

"Undang-Undang Nomor 25 Tahun 1992 Tentang Perkoperasian," 1992. 